\title{
We ...with Anna: Inclusory coordination in Finnish and Fenno-Swedish ${ }^{1}$
}

\author{
Anders Holmberg \\ Newcastle University \\ Klaus Kurki \\ University of Turku
}

\begin{abstract}
Finnish and Fenno-Swedish both have a construction where a plural pronoun combined with a comitative adposition and a DP, as in 'we... with Anna', is interpreted as 'Anna and I'. The construction is found in several other languages east of the Baltic Sea but not in Scandinavia or, as far as we know, generally West Europe. In this paper, the main syntactic properties of the construction will be described. A related construction is found in Icelandic, where 'we Anna' means 'Anna and I'. This construction has recently been subject to a detailed examination in Sigurðsson \& Wood (2019). The Finnish and Fenno-Swedish construction will be compared with the Icelandic one. The fact that 'we...with Anna' unlike Icelandic 'we Anna' can be discontinuous means that it has more complex syntax. A generalization is proposed characterising the syntactic conditions on 'we...with Anna' in Finnish and Fenno-Swedish. A syntactic analysis will be proposed, in part following Sigurðsson \& Wood (2019) on the Icelandic counterpart.
\end{abstract}

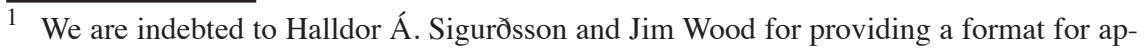
proaching the topic of inclusory coordination, and for much discussion about the right analysis. Thanks also to Camilla Wide for her encouragement and support, and discussion about Fenno-Swedish data. We are very happy to be part of a volume celebrating Sten Vikner's contribution to linguistics, particularly Germanic syntax. Like no-one else Sten has shown the power of micro-comparative investigation based on systematic and careful testing, always fuelled by positivity and good humour.

Ken Ramshøj Christensen, Henrik Jørgensen \& Johanna L. Wood (eds.). 2019.

The Sign of the V-Papers in Honour of Sten Vikner. Dept. of English, School of Communication \& Culture, Aarhus University, pp. 243-266, doi:10.7146/aul.348.98. (C) The author(s). 


\section{Introduction}

The following construction is common in Finnish and Fenno-Swedish, the dialect of Swedish spoken in Finland: ${ }^{2}$

(1) a. Finnish

Me mentiin Annan kanssa kaupunkiin.

We went.1PL Anna.GEN with town.ILL

'Anna and I went into town.'/ 'We went into town with Anna.'

b. Fenno-Swedish

Vi for med Anna till stan.

We went with Anna to town.DEF

'Anna and I went into town.'/ 'We went into town with Anna.'

In this construction a plural pronoun, most commonly 'we', is combined with another DP joined by a comitative adposition 'we...with DP', a postposition in Finnish, a preposition in Fenno-Swedish. The expression is ambiguous: in addition to the expected reading where it refers to a group of at least three people, it can refer to a group of two, 'DP and I', the preposition functioning like a conjunction. The construction is familiar from the literature (Schwartz 1988a, b; Lichtenberk 2000; Moravcsik 2003; Vassilieva \& Larson 2005; Haspelmath 2007; Dékány 2009; Cable 2017), found in Russian, for example. In some of the literature it is called the 'inclusory construction' or inclusory coordination (Lichtenberk 2000; Haspelmath 2007; Cable 2017), since the reference of the DP is included in the reference of the plural pronoun. The nomenclature is not optimal, as it does not capture the characteristic and most interesting feature of the construction, that the plural pronoun is interpreted as singular. Among Swedish dialects, and, as far as we know, Mainland Scandinavian more generally, inclusory coordination is only found in Fenno-Swedish, presumably due to contact with Finnish. The construction appears to be an areal phenomenon, being found in at least Russian, Polish (Cable 2017), Latvian (Schwartz 1988a), and Estonian ${ }^{3}$, among the languages east of the Baltic Sea, and also in Hungarian (Dékány 2009). It is closely related to a construction exemplified by Icelandic in (2):

\footnotetext{
2 The following abbreviations are used for Finnish cases: ADE $=$ adessive, $A L L=$ allative, $\mathrm{ELA}=$ elative, $\mathrm{ESS}=$ essive, $\mathrm{GEN}=$ genitive, $\mathrm{ILL}=$ illative, $\mathrm{PTV}=$ partitive.

3 Thanks to Anne Tamm.
} 
(2) Icelandic

Við Ólafur

We Ólaf

'I and Ólaf'

This construction, too, is inclusory coordination, but without the adposition. It is familiar from a number of other languages, but is apparently not very common cross-linguistically (Sigurðsson \& Wood 2019). The Icelandic version of it has recently been subject to a detailed examination in Sigurðsson \& Wood (2019), henceforth S\&W. They refer to it as Pro[NP]. As they indicate, the analysis that they propose for Pro[NP] can be adapted to the construction with a comitative adposition which we call Pro[with DP]. We also call the Icelandic construction Pro[DP], for reasons which will become clear. In the present paper we will check whether the properties that S\&W establish for Pro[NP] in Icelandic are, indeed, also found in the Finnish and Fenno-Swedish Pro[with DP] construction, and consider how the analysis that S\&W propose for Pro[DP] may be adapted to Pro[with DP] in Finnish and Fenno-Swedish. In the process we will also establish whether there are any differences between Finnish and Fenno-Swedish as regards Pro[with DP]. Since the Finnish and Fenno-Swedish construction, unlike Icelandic Pro[DP], can be discontinuous, the conditions on the placement of the two parts of the construction will be given special attention.

Following S\&W we will refer to the pronoun of inclusory coordination as Pro, and to the DP component as the DP annex, or just the annex. In the following, by 'Pro[with DP]' and 'Pro[with DP] reading' we refer to the construction/reading where formally plural Pro has singular reading.

The grammaticality judgements in the paper are our own, in some cases checked with a few other speakers. They need to be confirmed by experiments and, where possible, corpus data. We leave this for future research.

\section{Some general properties of Pro[with DP]}

\subsection{Constituent or not}

The construction can be a constituent, although it is more commonly discontinuous, with Pro typically occupying the standard grammatical subject position (spec of TP) while the annex is in a position lower down in the TP-domain, outside vP (see sections 2.3 and 6 for more details). 


\section{(3) Fenno-Swedish}

a. Vi med Anna har aldrig varit till Lanzarote. We with Anna have never been to Lanzarote 'Anna and I have never been to Lanzarote.'

b. Vi har med Anna aldrig varit till Lanzarote. We have with Anna never been to Lanzarote 'Anna and I have never been to Lanzarote.'

(4) Finnish

a. Me Annan kanssaei olla koskaan oltu We Anna.GEN with not have ever been

Lanzarotella.

Lanzarote. $A D E$

'Anna and I have never been to Lanzarote.'

b. Me ei Annan kanssa olla koskaan oltu We not Anna.GEN with have ever been

Lanzarotella.

Lanzarote. $A D E$

'Anna and I have never been to Lanzarote.'

The position of the annex in the discontinuous version is a complicated matter which we will mainly leave for future research. It may be noted, though, that the position of the annex in relation to adverbs and auxiliaries in the TP-domain is somewhat free. For example (5) and (6) are acceptable as well, alongside (3) and (4).

\section{(5) Fenno-Swedish}

Vi har aldrig med Anna varit till Lanzarote.

We have never with Anna been to Lanzarote.

'Anna and I have never been to Lanzarote.'

(6) Finnish

Me ei olla Annan kanssa koskaan oltu Lanzarotella.

We not have Anna.GEN with ever been Lanzarote.ADE

'Anna and I have never been to Lanzarote.' 
In (7), the annex is predicate-internal. This, too, is possible.

\section{(7) Fenno-Swedish}

Vi har aldrig varit med Anna till Lanzarote.

We have never been with Anna to Lanzarote.

'We have never been to Lanzarote with Anna.'

'Anna and I have never been to Lanzarote.'

(8) Finnish

Me ei olla koskaan oltu Annan kanssa Lanzarotella.

We not have ever been Anna.GEN with Lanzarote.ADE

'We have never been to Lanzarote with Anna.'

'Anna and I have never been to Lanzarote.'

In all of these sentences 'we' can be interpreted as singular or plural, but with a difference in preferences. The singular reading is preferred in (3) and (4), while the plural reading is at least equally preferred to the singular in (7) and (8).

\subsection{No reversal}

The construction cannot be reversed, the DP annex occupying the subject position and the pronoun the lower position. Here and in the following '\#' signifies that the sentence is grammatical but lacks the (singular) inclusory coordination reading. Thus $(9,10)$ cannot mean that Anna and I went into town.

(9) Fenno-Swedish

\#Anna for med oss till stan.

Anna went with us to town.DEF

'Anna went into town with us.'

(10) Finnish

\#Anna meni meidän kanssa kaupunkiin.

Anna went we.GEN with town.ILL

'Anna went into town with us.'

This is also characteristic of Pro[DP] (S\&W). 


\subsection{The highest argument condition}

Pro[with DP] is most typically subject, preferably subject of a finite clause. This is just a tendency, though. The more precise characterization of the place of Pro[with DP] in the structure turns out to be a complex matter, particularly in Finnish, due to the greater flexibility of sentential word order in Finnish. The following is a set of observations and a hypothesis, to be tested in future research based on grammaticality judgment experiments and, where possible, corpus data.

Some positions seem impossible as hosts for Pro[with DP]. It cannot, for instance, be possessor in a possessive DP. In this respect Finnish and Fenno-Swedish Pro[with DP] is different from Icelandic Pro[DP]; according to $\mathrm{S} \& \mathrm{~W}, \mathrm{Pro}[\mathrm{DP}]$ is free to occur in all grammatical functions.

\section{(11) Fenno-Swedish}
a. *Det här är vår med Annas katt. This here is our with Anna.GEN cat
b. *Det här är vår katt med Anna. This here is our cat with Anna

\section{(12) Finnish}
a. *Tämä on meidän Annan kanssa kissa. This is our Anna.GEN with cat
b. *Tämä on meidän kissa Annan kanssa This is our cat Anna.GEN with

In $(13 \mathrm{a}, 14 \mathrm{a})$ Pro[with DP] is object of a transitive verb. In $(13 \mathrm{~b}, 14 \mathrm{~b})$ it is object of a ditransitive object control verb. The singular Pro[with DP] reading 'Anna and I' appears not to be possible.

\section{(13) Fenno-Swedish}

a. \#Såg du oss med Anna där? Saw you us with Anna there 'Did you see us there with Anna?'

b. \#De bad oss fara med Anna till stan. They asked us go with Anna to town.DEF 'They asked us to go into town with Anna.' 


\section{(14) Finnish}

a. \#Näitkö meidät Annan kanssa siellä?

Saw.2PL.Q we.ACC Anna.GEN with there

'Did you see us there with Anna?'

b. \#Ne pyysi meitä tulemaan Annan kanssa

They asked we.PTV come Anna.GEN with

kaupunkiin.

town.ILL

'They asked us to come into town with Anna.'

In (15), the construction is the subject of an infinitival clause with exceptional case marking (ECM). Our judgment is that it is marginally better than the object cases in (13) with a singular reading of 'we'.

\section{(15) Fenno-Swedish}

?Panelen ansåg oss nog med Anna vara allt för Panel.DEF considered us PRT with Anna be all too oerfarna. inexperienced

'The panel considered us/me and Anna to be too inexperienced.'

Finnish does not have ECM-infinitivals, but (16) exemplifies a participial complement clause, a non-finite clause type functioning as object of verbs of saying, thinking, and wanting (Kiparsky 2018).

\section{(16) Finnish}

?Paneeli ajatteli meidän Annan kanssa olevan liian Panel thought we.GEN Anna.GEN with be.PTC too kokemattomia. inexperienced

'The panel considered us/me and Anna to be too inexperienced.'

As with (15), we consider it marginally better than (14a,b) with a singular reading of 'we', consistent with the generalization that Pro[with DP] must be subject.

Consider the following sentences, though. 


\section{(17) Finnish}

a. \#Se nuori tarjoilija palvelee meitä Annan kanssa. The young waiter.NOM serves we.PTV Anna.GEN with 'The young waiter and Anna are serving us.'

b. Meitä Annan kanssa palvelee se nuori tarjoilija. We.PTV Anna.GEN with serves the young waiter 'Anna and I are served by the young waiter (not the old one).'

These examples show that subjecthood in the sense of 'highest thematic argument' is not crucial. In (17a) the Pro[with DP] reading of meitä Annan kanssa is not available; the reading is that the waiter and Anna served us. But in (17b), where the object is fronted, the Pro[with DP] reading is possible. The fronted object is in the 'T-position' (suggesting 'topic') of Vilkuna (1989), called spec-F(inite)P in Holmberg \& Nikanne (2002). This is the position that the thematic subject occupies, in unmarked cases, but which may be, and in some cases has to be, filled by a non-subject, interpreted as topic, as in (17b), where the subject remains in a low focusposition. It is identified as a mixed A- and A-bar position by Holmberg \& Nikanne (2002); see also Brattico (2018). A simple test that this position is the same position as is occupied by the subject in the unmarked case is that it inverts with the verb, moved to $C$ in yes-no questions (see Holmberg \& Nikanne 2002 for other tests).

\section{(18) Finnish}

a. Palveleeko se nuori tarjoilija meitä Annan kanssa? Serves.Q the young waiter we.PTV Anna.GEN with 'Is the young waiter serving us and Anna?' 'Is the young waiter and Anna serving us?'

b. Palveleeko meitä Annan kanssa se nuori tarjoilija? Serves.Q we.PTV Anna.GEN with the young waiter 'Is the young waiter serving me and Anna?'

The contrast between $(17 \mathrm{a}, \mathrm{b})$ indicates that the Pro[with DP] reading is associated with the structurally highest, rather than thematically highest argument position. 
In Fenno-Swedish, as in the Scandinavian languages generally, object fronting is clearly movement to A-bar position in the C-domain (Holmberg 1986; Holmberg \& Platzack 1995; Vikner 1995). As might be expected, the (singular) Pro[with DP] reading appears not to be available. In (19a), the object 'us with Anna' is in situ, in (19b) it has been fronted. In neither case is the Pro[with DP] reading available.

\section{(19) Fenno-Swedish}

a. \#Den unga servitören serverade oss med Anna. The young waiter served us with Anna 'The young waiter served us with Anna.'

'The young waiter and Anna served us.'

b. \#Oss med Anna serverade den unga servitören. Us with Anna served the young waiter 'It was the young waiter who served us and Anna.'

The relevant syntactic difference between Finnish and Fenno-Swedish is, then, that Finnish has a position hosting the subject or a topicalized object or adverbial, with A-position properties, absent in Fenno-Swedish.

(20) exemplifies another condition.

\section{(20) Finnish}

Verkkosivusto palvelee kyllä meitä Annan kanssa
Website serves PRT we.PTV Anna.GEN with
(vaikka sitä kaikki muut moittiikin).
(although it.PTV all others criticize.even)
'The website does serve me and Anna
(even though everyone else criticises it).'

The Pro[with DP] reading is available here even though it is not the structurally highest argument. The difference between (20) and (17a) is that the structurally highest argument (the subject) in (20) is inanimate. This suggests the following generalization:

(21) Pro[with DP] is possible if and only if it is the structurally highest human argument. 
Finnish has a number of constructions in which a non-nominative argument shows up in a high argument position, including the following ones. As shown, in all of them Pro[with DP] is available for that argument. ${ }^{4}$

\section{(22) Finnish}

a. Meitä Annan kanssa harmittaa, että myöhästyttiin. We.PTV Anna.GEN with annoys that were.late.1PL 'It annoys me and Anna that we were later.'

b. Meille Annan kanssa on selvää, että matkustelu on We.ALL Anna.GEN with is clear that travelling is kallista. expensive

'It's clear to me and Anna that travelling is expensive.'

c. Meistä tuntuu Annan kanssa suorastaan pahalta We.ELA feels Anna.GEN with outright unpleasant se meteli. that noise

'To me and Anna that noise feels outright unpleasant.'

d. Meistä tulee Annan kanssa isoina laulajia. We.ELA come Anna.GEN with big.ESS singers 'Anna and I will become singers when we grow up.'

Whether the initial phrase in all of them is the subject or not may be debatable, but it is uncontroversially in the T-position, as can be verified by the 'yes-no inversion test'. As such they allow the Pro[with DP] reading. $(22 a, b, c)$ have the alternative word orders $(23 a, b, c, d)$.

\section{(23) Finnish}

a. Se että myöhästyttiin harmittaa meitä Annan kanssa. It that were.late.1PL annoys we.PTV Anna.GEN with 'It annoys me and Anna that we were late.'

4 The verb form myöhästyttiin in (22a) and (23a,b) is strictly speaking an impersonalpassive form widely used as 1PL in colloquial Finnish. The standard Finnish form would be myöhästyi-mme, with a 1PL suffix -mme. The judgments would be the same with that form, except for a slight stylistic incongruity. We have chosen to gloss the colloquial form as 1PL. 
b. Se harmittaa meitä Annan kanssa että myöhästyttiin. It annoys we.PTV Anna.GEN with that were.late.1PL 'It annoys me and Anna that we were late.'

c. Että matkustaminen on kallista on meille That travelling is expensive is we.ALL

Annan kanssa selvää.

Anna.GEN with clear

'That travelling is expensive is clear to me and Anna.'

d. Meteli tuntuu meistä Annan kanssa suorastaan Noise feels we.ELA Anna.GEN with outright

pahalta.

unpleasant

'The noise feels outright unpleasant to me and Anna.'

As predicted by (21), they all allow the Pro[with DP] reading, since the initial phrase in the T-position, the highest argument position, is inanimate. $(24 a, b)$ suggest that condition (21) holds in Fenno-Swedish as well.

\section{(24) Fenno-Swedish}

a. Det retade oss nog med Anna att vi kom för sent. It annoyed us PRT with Anna that we came too late 'It did annoy me and Anna that we were late.'

b. Att vi kom för sent retade oss nog med Anna. That we came too late annoyed us PRT with Anna 'It did annoy me and Anna that we were late.'

As already pointed out, these judgments need to be confirmed by proper grammaticality judgment experiments and, where possible, corpus data.

\section{Properties of the pronoun in Pro[with DP]}

\subsection{We, you, they}

Our impression is that the most common instantiation of Pro[with DP] is with 'we', but it can be 'you.PL' or, perhaps more marginally, 'they', in Finnish as well as in Fenno-Swedish. 
(25) a. Fenno-Swedish

När var ni sist med Anna till Lanzarote?

When were you.PL last with Anna to Lanzarote

'When were you and Anna in Lanzarote the last time?'

b. Finnish

Milloin te viimeksi olitte Annan kanssa

When you.PL last were.2PL Anna.GEN with

Lanzarotella?

Lanzarote. $A D E$

'When were you and Anna in Lanzarote the last time?'

(26) a. Fenno-Swedish

Question: Var är Hasse?

Where is Hasse

'Where is Hasse?'

Answer: De for med Anna till stan.

They went with Anna to town.DEF

'He and Anna went into town.'

b. Finnish

Question: Missä Hasse on?

Where Hasse is

'Where is Hasse?'

Answer: Ne meni Annan kanssa kaupungille.

They went Anna.GEN with town.ALL

'He and Anna went into town.'

The reason why 'we' is most common could be simply that it is more common to make a statement about one's own pursuits together with somebody than the addressee's or someone else's pursuits with somebody.

The plural component has to be a pronoun, though. 
(27) Fenno-Swedish

Question: Var är Elsa?

Where is Elsa

'Where is Hasse?'

Answer: Flickorna for med Anna till stan.

Girls.DEF went with Anna to town.DEF

'The girls went into town with Anna.'

\section{(28) Finnish}

Question: Missä Elsa on?

Where Elsa is

'Where is Elsa?'

Answer: Tytöt meni Annan kanssa kaupunkiin. Girls.NOM went Anna.GEN with town.ILL

'The girls went into town with Anna.'

(27) and (28) cannot mean 'The girls Elsa and Anna went into town'; the reference of the initial DP is necessarily plural: 'The girls went into town together with Anna'.

\subsection{Pro drop in Pro[with DP]}

Like other Germanic languages, Fenno-Swedish does not have pro drop except under highly restricted conditions: topic drop, expletive drop, diary drop (Haegeman 1990, 2013; Holmberg 2003; Sigurðsson 2011). It is possible, in fact, that topic drop and expletive drop are even less commonly employed in Fenno-Swedish than in (some) other varieties of Swedish. We cannot construct a natural sentence with pro drop of vi 'we' under any reading, so it is not surprising that we do not find it with Pro[with DP] (as shown by S\&W, Icelandic Pro[DP] does not allow pro drop, either). However, Finnish is a pro drop language, with optional pro drop of 1st and 2nd person pronouns (see Vainikka \& Levy 1998; Holmberg 2005). As shown by the examples in (29), pro drop can apply in Pro[with DP]. ${ }^{5}$

5 In standard Finnish the 1PL form of the verb has a suffix -mme; see note 4 . The standard form appears not to be impossible, either, with pro drop.

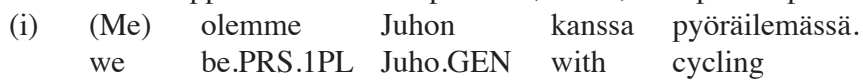

'Me and Juho are out cycling.' 
(29) Finnish

a. Menittekö (te) Annan kanssa eilen

Went.2PL.Q you.PL Anna.GEN with yesterday

kaupungille?

town.ALL

'Did you and Anna go into town yesterday?'

b. (Me) ollaan Juhon kanssa pyöräilemässä.

(We) are.1PL Juho.GEN with cycling

'Me and Juho are out cycling.'

\subsection{No expansion of Pro}

As S\&W note for Icelandic Pro[DP], Pro cannot be expanded in Pro[with DP].

(30) Fenno-Swedish

\#Vi på Grannas for med Anna till stan.

We at Grannas went with Anna to town.DEF

'We at Grannas went into town with Anna.' (Grannas a farm)

(31) Finnish

\#Me raisiolaiset mentiin kaupungille Annan kanssa.

We Raisio.people went.1PL town.ALL Anna.GEN with

'We Raisioites went into town with Anna.'

(30) and (31) cannot mean 'Me and Anna, who are from Grannas/Raisio, went into town'.

The interplay of the pronoun and the quantifier 'both' is somewhat complex, and will be left for future research. However, when forming a constituent with the plural pronoun, the two cannot function as Pro in Pro[with DP].

(32) Fenno-Swedish

\#Vi båda for med Anna till stan.

We both went with Anna to town.DEF

'We both went into town with Anna.' 
(33) Finnish

\#Me molemmat mentiin Annan kanssa kaupungille.

We both went.1PL Anna.GEN with town.ALL

'We both went into town with Anna.'

\section{Properties of the annex}

The annex is typically a proper name or a kinship term (as S\&W note for Pro[DP]), but need not be: It can be a definite DP based on a common noun, and even an indefinite DP as long as it is specific. It can be plural or singular.

\section{(34) Fenno-Swedish}

a. Vi for med mamma till stan.

We went with mother to town.DEF

'Me and mother went into town.'

b. Vi satt med pojkarna och diskuterade framtiden.

We sat with boys.DEF and discussed future. $D E F$

'Me and the boys sat down and discussed the future.'

c. Vi stod med en annan passagerare

We stood with one other passenger

och väntade på en buss som aldrig kom.

and waited on one bus that never came

'Me and another passenger stood waiting for a bus that never came.'

\section{(35) Finnish}

a. Me mentiin äidin kanssa kaupunkiin.

We went.1PL mother.GEN with town.ILL

'Me and mother went into town.'

b. Me istuttiin pomon kanssa ja keskusteltiin

We sat.1PL boss.GEN with and discussed.1PL

tulevaisuudesta.

future.ELA

'Me and the boss sat down and discussed the future.' 
c. Me siinä yhden toisen matkustajan kanssa

We there one.GEN other.GEN passenger.GEN with

odotettiin bussia, joka ei tullutkaan

awaited bus.PTV which not came.even

'Me and another passenger waited for a bus that didn't come in the end.'

(36) does not have the Pro[with DP] reading (see S\&W). The reason would seem to be that a bare indefinite plural can only be interpreted as nonspecific.

\section{(36) Fenno-Swedish}

$\# \mathbf{V i}$ for med lingvister till Oslo.

We went with linguists to Oslo

'We went with linguists to Oslo.'

In Finnish the distinction between plural definite and indefinite cannot be made in this construction, as Finnish lacks articles.

The annex cannot very well be a $2^{\text {nd }}$ person pronoun.

(37) Fenno-Swedish

?\#Jag kommer ihåg när vi var med dig på teater.

I come in.mind when we were with you on theatre

'I remember when we went with you to the theatre.'

(38) Finnish

?\#Mä muistan sen kun me oltiin sun kanssa

I remember it when we were you.SG.GEN with teatterissa.

theatre.INE

'I remember when we went with you to the theatre.'

This sentence seems not to have the 'me and you' interpretation. This may be a redundancy effect rather than a grammatical condition. The annex does not provide any information that is not already part of the unmarked interpretation of inclusive 'we': 'me and you'. 
A $3^{\text {rd }}$ person pronoun may also be somewhat unusual as annex, but examples can be constructed which sound natural enough, in Finnish as well as Fenno-Swedish.

\section{(39) Fenno-Swedish}

Vet du Hasse? Vi var en gång med honom

Know you Hasse We were one time with him

helt ensamma på bussen till Helsingfors.

all alone on bus.DEF to Helsinki

'You know Hasse, right? We were once all alone, him and me, on the bus to Helsinki.'

\section{(40) Finnish}

Sinä tiedät Hassen? Me oltiin kerran hänen

You know.2SG Hasse? We were.1PL once he.GEN

kanssa kahestaan Helsingin bussissa.

with two.of Helsinki.GEN buss.INE

'You know Hasse, right? We were once all alone, him and me, on the bus to Helsinki.'

\section{The syntactic derivation of Pro[with DP]}

S\&W propose that the structure of Pro[DP] and Pro[with DP] is essentially the same, based on the observation that they have the same meaning, in addition to obvious lexical and linear correspondences. We will adopt part of this hypothesis here.

Following S\&W (see also Vassilieva \& Larson 2005 and Dékány 2009) we assume that plural pronouns are composed of two variables $\{\mathrm{X}, \mathrm{Y})$. In the case of 'we', the first variable has the value 'speaker', hence XSP(EAKER). The second variable is context-dependent. To put it simply, 'we' means 'I and some contextually determined person or group' (but see Sigurðsson 2017 for some qualification of this analysis). However, in the case of Pro[(with) DP] it can be assigned a value (an interpretation) by the DP annex. This is how vi...med Anna (FennoSwedish) and me...Annan kanssa (Finnish) end up denoting 'me and Anna'. So, what is the syntactic relation between Pro and the annex? ${ }^{6}$ The fact that the pronoun cannot be expanded (see 3.3) indicates that the pronoun is a head, a D. On the other hand, the fact that the pronoun in

6 At the time of writing, S\&W is still under revision. We therefore cannot represent or discuss the precise version of the analysis of Pro[(with) NP] in S\&W. 
Fenno-Swedish and Finnish can move to the subject position, stranding the PP, indicates that it is a DP. We propose that it is, indeed, a DP, made up of $\mathrm{D}$ and a PP, as shown in (41). The verb undergoes movement from $\mathrm{V}$ to $\mathrm{V}$ (as standardly assumed), and subsequently from there to T. ${ }^{7}$

\section{(41) Fenno-Swedish}

a. Vi såg med Anna en varg.

We saw with Anna a wolf

'Me and Anna saw a wolf.'

b.

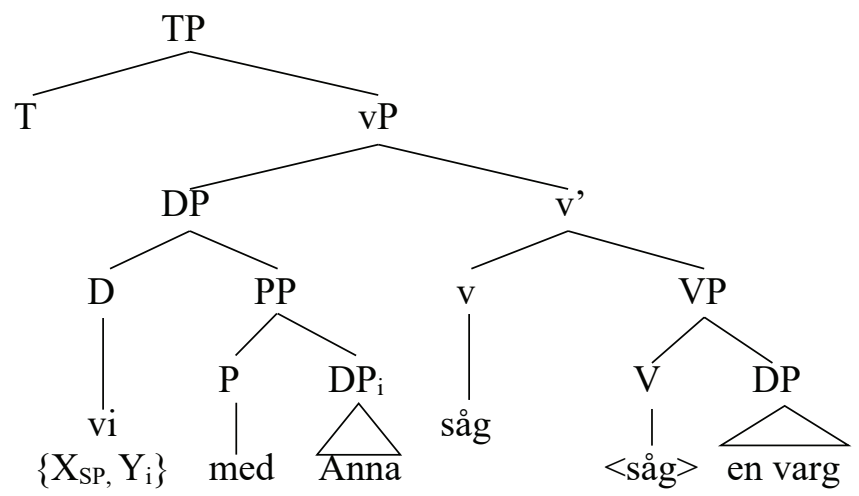

The Finnish tree is identical, except that the PP is head-final. In (41), the Y-variable has been assigned the referential index of the DP Anna. Now the DP vi med Anna /me Annan kanssa can undergo movement as such to specTP. This has happened in (3) and (4). Alternatively (and more commonly), the PP first undergoes movement out of the DP, adjoining to vP, or, if there are other constituents between $\mathrm{T}$ and $\mathrm{vP}$ such as adverbs or auxiliary verbs, the PP may move higher up, adjoining to the phrase dominating the adverbs or auxiliaries. Subsequently the remnant DP moves to the subject position, and the verb, if it is the highest verb, moves to T. Compare $(42,43)$ : In (42) the annex PP has adjoined to the lowest vP, below the adverb en gång 'once', before the remnant subject has moved to spec-TP and the verb to T.

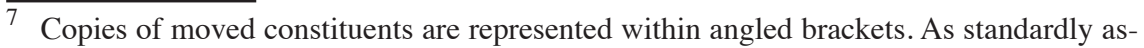
sumed for V2 languages, the finite verb in main clauses moves on to $\mathrm{C}$ and the subject to spec-CP (Vikner 1995; Holmberg 2015). We ignore this here 
(42) Fenno-Swedish

a. Vi såg en gång med Anna en varg.

We saw one time with Anna a wolf

'Me and Anna once saw a wolf.'

b.

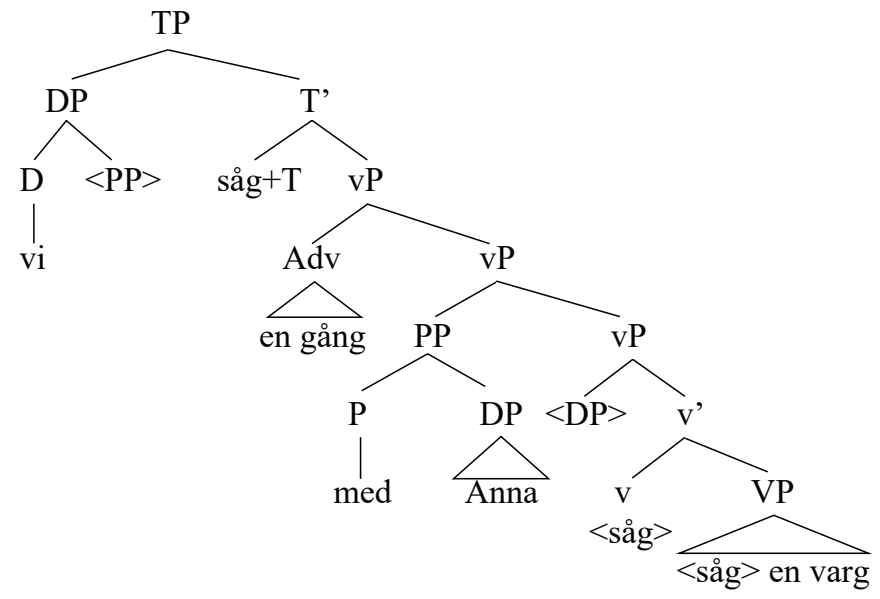

In (43), the annex PP has adjoined to the vP dominating the adverb.

\section{(43) Fenno-Swedish}

a. Vi såg med Anna en gång en varg.

We saw with Anna one time a wolf

'Anna and I once saw a wolf.'

b.

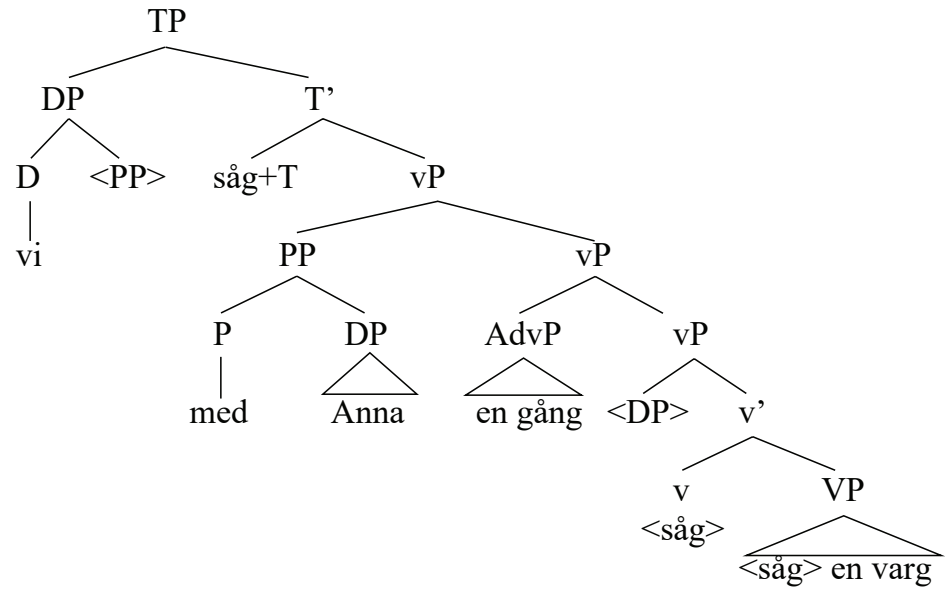


In this way we can explain the apparently free placement of the annex PP in the space between $T$ and the verb in the two languages. Example (44) seems to show that the placement of the annex PP is even freer in Finnish than in Fenno-Swedish: In Finnish but not in Fenno-Swedish, the PP can occur between the non-finite verb and the object.

(44) a. Finnish

Me ollaan jo syöty Annan kanssa päivällistä.

We have.1PL already eaten Anna.GEN with dinner

'Anna and I have already had dinner.'

\section{b. Fenno-Swedish}

*Vi har redan ätit med Anna middag.

We have already eaten with Anna dinner

This is predicted, however, under the analysis, discussed in Holmberg et al. (1993) and Holmberg (2001), according to which the non-finite main verb optionally undergoes movement out of vP in Finnish, possibly to an Aspect head. The structure of the relevant section of (44a) would be (45).

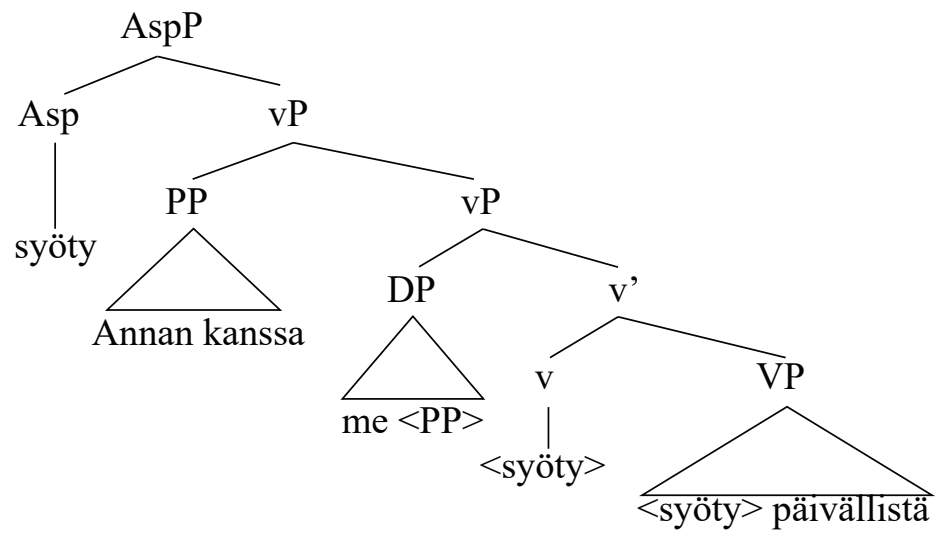

Here the PP has moved out of the DP, adjoining to vP, while the verb has moved first to v, and then to Asp. Subsequently the rest of the constituents in (44a) are merged, and the remnant subject moves to spec-TP, deriving the word order in (44a). In Fenno-Swedish there is no head-movement of 
the non-finite verb out of $\mathrm{vP}$, so the word order in (44b) cannot be derived.

Why Pro cannot be expanded can also be understood if the relation between the Y-variable in Pro and the annex NP/DP is a 'probe-goal' relation (Chomsky 2001): The variable can only be valued by a local DP in its c-command domain. In $(30,31)$ the PP pa Grannas and the NP raisiolaiset 'Raisio.people', respectively, are sisters of Pro, meaning that the presumptive annex is not c-commanded by Pro.

Why (36), with a non-specific annex, is ungrammatical can also be explained: the non-specific annex does not have a referential index that could value the Y-variable. It is an NP, a predicate, not a DP (a reason for calling the grammatical annex [(with) DP] rather than [(with) NP], as in $\mathrm{S} \& \mathrm{~W})$.

We may have at least the beginning of an explanation of generalization (21): Pro[with DP] is possible if and only if it is the structurally highest human argument. What we can observe is that sentence (17a), which violates the generalization, is ambiguous: the PP Annan kanssa 'with Anna' can be construed with the object me 'we' or the subject se nuori tarjoilija 'the young waiter'. The alternative (17b) where Pro[with DP] is fronted does not have this ambiguity. If the Pro[with DP] reading is a marked option, this could be the explanation why that reading is unavailable in (17a). In (20), as well, there is no ambiguity, and the Pro[with DP] reading is available. This explanation also fits with the observation that the Icelandic Pro[DP] construction is as good in object as in subject position. In Icelandic, the annex DP always forms a constituent together with Pro, thus cannot be construed with any other head or argument. Whether the explanation from ambiguity can be extended to all other cases of ungrammatical or unavailable Pro[with DP] in object position is a question we shall leave for future research. For one thing, we need more confirmation of our intuitions regarding the availability of the Pro[with DP] reading in various contexts.

\section{Conclusions}

Finnish and Fenno-Swedish both have a construction which, partly following S\&W, we have dubbed Pro[with DP], called 'the inclusory construction' in some of the literature. In Pro[with DP] a plural pronoun, usually 'we', is in construction with a comitative preposition and an object, called the annex, but is interpreted as a singular pronoun coordinated with the annex. The aim of the paper is mainly descriptive: We have described 
its syntactic properties, including properties of the pronoun, the DP annex, and the structural relation between the two parts when they are separated, as they very often are. We have proposed a generalization characterising the syntactic conditions on the Pro[with DP] interpretation: Pro[with DP] has to be the structurally highest argument with human reference. Following $\mathrm{S} \& \mathrm{~W}$, we have assumed that 'we' is a set of two variables $\{\mathrm{X}, \mathrm{Y}\}$. One is valued 'speaker', while the other is contextually determined. In Pro[with DP], however, the second variable is valued by the annex DP. This yields the reading 'Anna and I' for Finnish me...Annan kanssa and Fenno-Swedish vi...med Anna. We have also presented a formal account of the movements which Pro[with DP] undergoes, when the pronoun is separated from the annex. The formal account can explain at least a subset of the properties that the construction exhibits. Our findings so far indicate that the Finnish and the Fenno-Swedish construction have very similar properties. Where they differ, this can be explained in terms of the greater flexibility of word order (movement) in the TP domain in Finnish, compared with FennoSwedish.

\section{References}

Brattico, Pauli. 2018. Word order and adjunction in Finnish. Beder: Aquila \& Celik.

Cable, Seth. 2017. Some observations on the plural pronoun construction of Tlingit, Polish, and Russian. In Claire Halpert, Hadas Kotek \& Coppe van Urk (eds.), A pesky set: Papers for David Pesetsky. Cambridge, MA: MIT Working Papers in Linguistics 80.

Chomsky, Noam. 2001. Derivation by phase. In Michael Kenstowicz (ed.), Ken Hale: A life in language, 1-59. Cambridge, MA: MIT Press.

Dékány, Éva 2009. Comitative adjuncts: Appositives and non-appositives. In E. Kiss Katalin (ed.), Adverbs and adverbial adjuncts at the interfaces, 231-244. Berlin: Mouton de Gruyter.

Haegeman, Liliane. 1990. Non-overt subjects in diary contexts. In Joan Mascaro \& Marina Nespor (eds.), Grammar in progress, 167-174. Dordrecht: Foris. doi:10.1515/9783110867848.167.

Haegeman, Liliane. 2013. The syntax of registers: Diary subject omission and the privilege of the root. Lingua (SI: Syntax and Cognition: Core Ideas and Results in Syntax) 130. 88-110. doi:10.1016/j.lingua.2013.01.005. 
Haspelmath, Martin. 2007. Coordination. In Timothy Shopen (ed.), Language typology and syntactic description. Volume II: Complex constructions, 1-51. Cambridge:CambridgeUniversityPress.doi:10.1017/CBO9780511619434.001. Holmberg, Anders. 1986. Word order and syntactic features in the Scandinavian languages and English. Stockholm: Stockholm University dissertation.

Holmberg, Anders. 2001. The syntax of yes and no in Finnish. Studia Linguistica 55. 141-175. doi:10.1111/1467-9582.00077.

Holmberg, Anders. 2003. Topic drop or VP focus? In Lars-Olof Delsing, Cecilia Falk, Gunlög Josefsson \& Halldor Sigurðsson (eds.), Grammar in focus: Festschrift for Christer Platzack, 18 Nov. 2003, vol. 2, 159-166. Lund: Lund University.

Holmberg, Anders. 2005. Is there a little pro? Evidence from Finnish. Linguistic Inquiry 36(4). 533-564. doi:10.1162/002438905774464322.

Holmberg, Anders. 2015. Verb second. In Tibor Kiss \& Artemis Alexiadou (eds.), Syntax: An international handbook of contemporary syntactic research, 2nd edn. (HSK Series), 343-384. Berlin: Walter de Gruyter Verlag.

Holmberg, Anders, Urpo Nikanne, Irmeli Oraviita, Hannu Reime \& Trond Trosterud. 1993. The structure of INFL and the finite clause in Finnish. In Anders Holmberg \& Urpo Nikanne (eds.), Case and other functional categories in Finnish syntax, 177-206. Berlin: Mouton de Gruyter. doi:10.1515/9783110902600.177.

Holmberg, Anders \& Urpo Nikanne. 2002. Expletives, subjects and topics in Finnish. In Peter Svenonius (ed.), Subjects, expletives, and the EPP, 71-106. Oxford: Oxford University Press.

Holmberg, Anders \& Christer Platzack. 1995. The role of inflection in Scandinavian syntax. Oxford: Oxford University Press.

Kiparsky, Paul. 2018. Notes on Finnish nonfinite clauses. https://web.stanford. edu/ kiparsky/Papers/karttunen.fs.pdf (05 March, 2018.)

Lichtenberk, Frantisek. 2000. Inclusory pronominals. Oceanic Linguistics 39. 1-32. doi:10.1353/ol.2000.0006.

Moravcsik, Edith. 2003. A semantic analysis of associative plurals. Studies in Language 27. 469-503. doi:10.1075/s1.27.3.02mor.

Schwartz, Linda. 1988a. Asymmetric feature distribution in pronominal 'coordinations'. In Michael Barlow \& Charles Ferguson (eds.), Agreement in natural language: Approaches, theories, descriptions, 237-249. Stanford, CA: Center for the Study of Language and Information.

Schwartz, Linda. 1988b. Conditions on verb-coded coordinations. In Michael Hammond, Edith Moravcsik \& Jessica Wirth (eds.), Studies in syntactic typology, 53-73. Amsterdam: John Benjamins.

Sigurðsson, Halldor Á. 2011. Conditions on argument drop. Linguistic Inquiry 42(2). 267-304. doi:10.1162/LING_a_00042. 
Sigurðsson, Halldor Á. 2017. Who are we - and who is I? About person and SELF. In Michelle Sheehan and Laura Bailey (eds.), Order and structure in syntax II: Subjecthood and argument structure. Berlin: Language Science Press. http:// langsci-press.org/catalog/book/115

Sigurðsson, Halldor Á \& Jim Wood. 2019. We Ólaf, you linguists: Pro[(x) NP] constructions in Icelandic and beyond. Unpublished ms.

Vainikka, Anne \& Yonata Levy. 1999. Empty subjects in Finnish and Hebrew. Natural Language and Linguistic Theory 17. 613-671. doi:10.1023/A:1006225032592.

Vassilieva, Masha \& Richard K. Larson. 2005. The semantics of the plural pronoun construction. Natural Language Semantics 13(2). 101-124. doi:10.1007/ s11050-004-1031-5.

Vikner, Sten. 1995. Verb movement and expletive subjects in the Germanic languages. Oxford: Oxford University Press.

Vilkuna, Maria. 1989. Free word order in Finnish. Helsinki: Suomalaisen Kirjallisuuden Seura. 